\section{SOI: $1.1 /$ TAS $\quad$ DOI: $10.15863 /$ TAS International Scientific Journal Theoretical \& Applied Science}

p-ISSN: 2308-4944 (print) e-ISSN: 2409-0085 (online)

Year: $2015 \quad$ Issue: 03 Volume: 23

Published: $30.03 .2015 \quad$ http://T-Science.org

SECTION 21. Pedagogy. Psychology. Innovations in the field of education.
Valeriya Shotaevna Khetagurova Associate Professor, Candidate of geographical Sciences, Head of the Department of Social ecology and information law, Russian state social university, Russia vhetag@yandex.ru

\section{Galina Anatolyevna Bryukhanova} senior lecturer Russian state social university, Russia gal7717@yandex.ru

\title{
ASPECTS OF CONTINUITY OF ECOLOGICAL EDUCATION IN RUSSIA ON THE PATH TO SUSTAINABLE DEVELOPMENT
}

Abstract: The article raises the problem of formation of ecological education in Russia on the path to sustainable development. In the work are set and solved the following tasks: to define the essence of continuous environmental education; to reveal the mechanism of its social condition, an objective necessity; to analyze the implementation of social policy in the field of education and to show the main areas to create a unified system of continuous environmental education; to consider the peculiarities of the formation process of continuous environmental education in Russia. Principles and technology character; justified the structure and functions of the Institute of continuing environmental education, increase social efficiency of its functioning.

Key words: continuous environmental education, sustainable development, environmental security, environmental education.

Language: Russian

Citation: Khetagurova VS, Bryukhanova GA (2015) ASPECTS OF CONTINUITY OF ECOLOGICAL EDUCATION IN RUSSIA ON THE PATH TO SUSTAINABLE DEVELOPMENT. ISJ Theoretical \& Applied Science 03 (23): 126-137.

Soi: http://s-o-i.org/1.1/TAS*03(23)23 Doi: crossef http://dx.doi.org/10.15863/TAS.2015.03.23.23

\section{АСПЕКТЫ НЕПРЕРЫВНОСТИ ЭКОЛОГИЧЕСКОГО ОБРАЗОВАНИЯ В РОССИИ НА ПУТИ К УСТОЙЧИВОМУ РАЗВИТИЮ}

Аннотация: В статье поднимаются проблемы формирования экологического образования в России на пути к устойчивому развитию. В работе ставятся и решаются следуюшие задачи: определить сущность непрерывного экологического образования; раскрыть механизм его социальᄀной обусловленности, объективную необходимость; провести анализ реализации сочиальной полити ᄀки 6 сфере образования и показать основные ее направления по созданию единой системы непрерывного экологического образования; рассмотреть особенности становления процесса непрерывного экологического образования в России. Определены принщипы и характер технологии; обоснована структура и функции института непрерывного экологического образо-вания, пути повышения социальной эффективности его функиионирования.

Ключевые слова: непрерывное экологическое образование, устойчивое развитие, экологическая безопасность, экологическое просвещение.

\section{1. Введение}

Экологическое образование на современном этапе является не только лишь одним из аспектов учебного процесса. Оно проходит канвой через все периоды жизни человека, и способствует повышению качества общего образования. Процесс экологического образования и просвещения это наиболее подходящая база для формирования экологической культуры современного общества на данном этапе развития.
Поэтому, экологическое образование населения приобретает все большее значение в государственной и международной политике обеспечения экологической безопасности и устойчивого развития. Несмотря на то, что в целом уровень экологического сознания в России ниже, чем в странах Запада, в последнее время возникли идеи об особой роли России в мировом экологическом процессе. Основанием для подобного мнения служат два фактора. Во- 
первых, в настоящее время Россия является гарантом стабильности экосистемы Земли. Тропические леса в бассейне реки Амазонки и Центральной Африки, поддерживающие ранее мировой баланс кислорода на планете, в последние годы интенсивно вырубались. В России же при всей остроте экологического кризиса до сих пор сохранились 8 млн. км ${ }^{2}$ лесов Севера, Сибири и Дальнего Востока, обеспечивающие поступление кислорода в атмосферу Земли. Можно сказать, что планета дышит легкими России. Площадь российских лесов составляет около четверти мировых. Среди крупных развитых стран Россия имеет самую низкую среднюю антропогенную нагрузку на природные комплексы и самые высокие показатели устойчивости экосистем. Второй фактор, свидетельствующий о важной роли России в создании цивилизации, основанной на экологических принципах, связан со становлением экологического сознания. Индустриальное общество с его потребительской психологией изживает себя. Главная причина экологического кризиса - кризис духовный, погоня за материальными ценностями, отрыв от своих корней. Человек, зачастую исходя из ложных представлений о своих потребностях, вносит в окружающую природу необратимые изменения, к которым сам не успевает приспособиться. Актуальность данного исследования определена самой жизнью: преодоление кризиса в нашей стране, связанного с обновлением общественной системы в рамках демократического выбора, требует радикального повышения экологической образованности, профессионализма, культуры каждого человека. Своевременность поставленной проблемы состоит в том, что развитие российского общества, затрагивающее все сферы жизни невозможно без преобразования самого человека. На сегодня экология одна из самых проблемных и актуальных наук. Вопросы экологического образования неоднократно поднимаются общественными, политическими и государственными деятелями, учеными, общественностью. За последние годы предпринимаются попытки реформирования средней и высшей школы. На эти цели направляются значительные материальные и финансовые средства, затрачиваются солидные научные силы. А тем не менее ощутимых сдвиго пока еще не наблюдается. К сожалению, в настоящее время отмечается значительное количество функционально неграмотных, то есть людей, утративших минимум знаний, умений и навыков, который необходим для выполнения профессиональных задач и социальных функций. Это становится бедствием для государства, осложняет проблему выхода из кризиса. Возрождение российского общества требует основательной перестройки отечественного образования. Еще недавно однажды приобретенные человеком знания сохраняли свою ценность на протяжении всей его трудовой деятельности. Сейчас темпы обновления техники и технологий, особенно в наукоемких отраслях производства, стали превосходить темпы смены поколений людей. В этих условиях специалист вынужден неоднократно переучиваться.

Переход страны к рыночной экономике, демократизация общественной жизни требуют новых гражданских качеств. Они не могут быть заданы раз и навсегда. Необходимо постоянное обновление политических, экономических, экологических и правовых знаний, навыков управления производством, государственными и общественными делами. В условиях нарастающего динамизма общественной жизни экологическое образование призвано помочь каждому овладеть не только прочными знаниями, но и высокой психологической гибкостью, способностью воспринимать и применять новую информацию. Без этого человек неизбежно отстанет от хода истории, от общественного прогресса. В связи с этим необходимо пересмотреть устоявшиеся представления о социальной сущности экологического образования, переосмыслить его цель и задачи, принципы организации, структуру и функции, а также вопросы управления. Традиционно экологическое образование рассматривалось лишь в педагогическом аспекте. В специальной литературе оно трактуется как процесс и результат усвоения систематизированных знаний, т.е. как технология передачи знаний, обучение. Такое понимание образования правомерно в рамках педагогической науки, но оно раскрывает лишь одну из сторон данного явления, а не его сущность. Это сужает возможность теоретического осмысления актуальных проблем образования, их практическое решение. Основоположники марксизма неоднократно указывали на диалектическую взаимосвязь образования с социальными условиями. "С одной стороны, - говорил Карл Маркс, - для установления правильной системы образования требуется изменение социальных условий, с другой стороны, для того, чтобы изменить социальные условия, нужна соответствующая система образования". Движущими силами развития образования являются общественные по- 
требности, и потому стремление человека к образованности выступает источником богатства, основой общественного производства. Из этого вытекает методологически важный вывод: образование с точки зрения непосредственного процесса производства можно рассматривать как “производство основного капитала, причем этим основным капиталом является сам человек" [8, с. 158].

\section{2. Методология}

Основой данного исследования являются общенаучные принципы, методы и подходы исследования: диалектический, системный, аксиологический, экзистенциальный, структурнофункциональный, цивилизационный.

Цель исследования определяется проблемами формирования и развития непрерывного экологического образования в области экологической безопасности на современном этапе развития общества. В результате проведенной работы нами было решен ряд взаимосвязанных задач. Выявлена роль экологического образования и просвещения в разработке и осуществлении перехода к модели устойчивого развития; раскрыт механизм социальной обусловленности непрерывного экологического образования и его объективная необходимость; проведен анализа реализации социальной политики в сфере образования и показаны основные ее направления по созданию единой системы непрерывного образования. Кроме того, рассмотрены особенности организации процесса непрерывного образования, определены его цели, задачи и принципы, характер технологий; обоснованы структуры и функции института непрерывного экологического образования, пути повышения социальной эффективности его функционирования; исследованы системы непрерывного образования как объекта управления, предложены пути усовершенствования технологии планирования учебного комплекса.

В соответствии с намеченными задачами была разработана и методология исследования. Одним из основных методов исследования стал сравнительно-аналитический, основанный на детальном изучении опыта современных теоретиков и практиков в области экологической педагогики, социологии и социальной экологии. Также нами использовался и социоретроспективный метод исследования, основанный на изучении старых материалов с целью воссоздания историко-культурного процесса становления экологического образования в России. Кроме этого, применялся и синергетический метод исследования, заключающийся в широком использовании теоретического багажа смежных наук (ряда естественных наук, социологии, истории, географии, экономики и т.д.).

\section{3. Результаты}

3.1. Историко-культурный прочесс становления экологического образования в России

Термин «образование» имеет этимологический, семантический и философский смысл. Этимологическим и семантическим корнем его является «образ». Корень «образ» содержит значение понятия (семантический смысл) и его целевую нагрузку (философский смысл). Таким образом, слово «образование» генетически содержит в себе свою цель как образ предвидимого результата деятельности. То есть цель образования заложена в самом образовании в виде образа человека с определенными характеристиками. Эта специфика понятия «образование» нашла психолого-теоретическое подтверждение в работах видного советского ученого-психолога Бориса Федоровича Ломова (1927-1989гг.), который ввел в научный оборот понятие «образцель». Б.Ф.Ломов писал, что на основе имеющейся в его распоряжении информации человек формирует некоторый образ задаваемого (будущего) состояния объекта управления, т.е. образ того состояния, которое должно быть достигнуто в результате его деятельности [3, с. 54]. Первая в жизни человечества система образования была предложена Платоном. В ней на образование возлагалась задача формирования человека для выполнения им четко очерченных функций в соответствии с его социальным статусом. Этот статус был заранее обозначен. Он и задавал параметры «образа», «образца», его ценностей, выступавших ориентирами образовательной системы идеального государства. Согласно учению Платона, кандидаты в философы отбираются еще в детском возрасте в соответствии с природными задатками, которые впоследствии шлифуются, дополняются и развиваются особо направленным воспитанием и обучением. Платон обстоятельно описывал правила образования философов и воинов, указывая, с какого и до какого возраста, что, как, они должны изучать, чтобы соответствовать требованиям соответствующего образца. Система образования в представлении Платона - это умозрительная конструкция.

3.1.1 Становление $u$ развитие естествознания в дореволюичинной России

Теперь в ходе социо-ретроспективного анализа перейдем к рассмотрению реальной 
системы образования, существовавшей в Российской империи и СССР. Большой вклад в развитие экологического образования в XIX века внес русский ученый М.Ф. ВладимирскийБуданов, который в своей работе «Государство и народное образование» писал: «Государство не призвано служить интересам личности человека, а вся личность, со всею совокупностью моральных сил, есть покорный слуга государства» [1, с.27]. Утилитарный подход к учению определялся нуждами государства, а не общества, тем более не личности.

В первой половине XVIII в. в Россию проникают педагогические труды, например Я.А. Коменского [6, с.180] и Дж. Локка [10, с. 69]. Но, несмотря на проникновение европейской культуры термин «педагогика» был чужеродным и больше употреблялся в суженном виде «детоводец»» (от греческого слова). Педагогом в Древней Греции называли раба, который за руку водил ребенка своего господина в школу. Становлением педагогики и естествознания как научных дисциплин Россия обязана Екатерине II. По еe распоряжению были организованы воспитательные училища для детей обоего пола без общения с внешним миром и с очень ограниченным общением с родственниками. Она видела причину всех пороков людей в недостатке воспитания.

К 1917 году система образования в России отражала социальную структуру общества. Для детей дворян существовали закрытые даже для крупной буржуазии и чиновников учебные заведения - это были кадетские корпуса для мужчин, институты благородных девиц для женщин; кроме того особые школы для духовенства и учебные заведения для всех имущих (гимназии, реальные коммерческие училища). Для средних имущих сословий неполные средние городские училища с 6-летним сроком обучения, которые в 1912 г. были преобразованы в высшие начальные училища. Для детей низших сословий предназначались церковно-приходские школы, двухклассные училища.

Таким образом, становление естествознания как дисциплины стало возможным в процессе историко-культурного процесса формирования педагогики и наблюдалось на протяжении всей истории дореволюционной России. В XIX в. была заложена предметная структура школьного обучения во время дифференциации естественных наук, что явилось препятствием для успешного дальнейшего проведения экологообразовательного процесса.

$\begin{array}{ccc}3.1 .2 & \text { Социокультурный } & \text { анализ } \\ \text { образовательной ситуации в СССР } & \\ \text { Советское } & \text { государство } & \text { создало }\end{array}$

эффективную систему тотального формирования человека, максимально усваивавшего ценности, адекватные государственной идеологии. Поэтому, характеризуя «всеобъемлющую педагогическую систему», созданную в СССР, философ Даниил Леонидович Андреев (19061959 гг.), отмечал, что эта система «развивала смелость, но для защиты государства»; «развивала волю, но для выполнения директив государства»; «воспитывала чувство товарищества, но только к тем, кто за "наших", а кто против - тот враг»; «воспитывала честность и правдивость, но только такую, что была на пользу государству»; «воспитывала творческое отношение к труду, но только на пользу государству»; «поощряла жажду знаний, но только в строго направленном русле...» [11, c.102]. Пролетарский образец личности являлся универсальным, официально провозглашенным, единственным образцом для всех социальных и этнических групп Советского Союза. Интересы многообразных социальных групп общества игнорировались и были подменены интересами государства. Исходя из этих интересов, определялся и соответствующий социальный стандарт образования. Пролетарский личностный образец определял параметры системы образования, ее структуры, методы управления ею, содержание и методы обучения и воспитания. Первейшей и главнейшей задачей школы становилась идеологическая: то есть воспитание, формирование идейно-преданного, коммунистически верного, непримиримого к врагам и пережиткам прошлого гражданина. И лишь затем школа была призвана дать учащемуся строго отобранные, лимитированные, идейновыдержанные знания и сформировать у него определенные знания, умения и навыки.

Все то, что выходило за рамки заданных параметров, воспринималось как аномальное, было заведомо обречено, изживалось и объявлялось наследием прошлого или результатом влияния враждебных сил. Даже элитарные учебные заведения, предназначенные для удовлетворения профессиональных образовательных потребностей высших слоев советского общества, укладывались в рамки пролетарской культуры. В целом отношение к общеобразовательной школе у большинства населения было примерно одинаково и определялось унифицированностью школы, единообразием содержания образования, неизменностью программ, форм и методов обучения. Практически не существовало возможности выбора школы. Оценка учебного заведения производилась не по интеллектуальным, а этическим и географическим критериям. Таким образом, в 
советский период основным направлением в обучении были естественнонаучные, технические дисциплины, которые способствовали развитию научно-технического прогресса, в ущерб гуманитарным. Жесткий идеологический контроль не давал возможности для гуманизации общества, и как следствие, и развитию системы экологического образования.

3.1.3 Сочиально-исторические аспекты экологического образования в современной России (с 1991-201422.)

90-е гг. ХХ века вошли в историю России как время коренных преобразований общественного бытия. Однако в экологическом образовании не произошло такой смены парадигм, как в других сферах культуры и образования, поскольку изначально в нем были заложены многие установки, впоследствии взятые на вооружение всей педагогикой (личностно-ориентированный подход, интеграция личности в мировую культуру, формирование у учащихся картины мира, соответствующей современному уровню знаний и т.д.). Данный факт является подтверждением опережающего характера развития экологического образования, но влияние ряда внешних и внутренних факторов внесло в эту область просвещения определенные коррективы. К ним следует отнести: углубление экологического кризиса в мире; развитие общественного экологического сознания; интеграция страны в мировое сообщество. Кроме того, этому процессу способствовали такие факторы как: решения конференции в Рио-деЖанейро; появление таких документов, как “Закон Российской Федерации "Об охране окружающей среды” (1992г.), “Закон об образовании"(1992г.), "Национальный план действий Министерства экологии и природных ресурсов Российской Федерации по реализации решений конференции ООН по окружающей среде и развитию” (1993 г.); постановление № 4/1-6 от 30 марта 1994 г. Министерства образования Российской Федерации “Об экологическом образовании обучающихся в образовательных учреждениях Российской Федерации"; "Концепция перехода Российской Федерации к устойчивому развитию” (1996г.); рекомендации парламентских слушаний "Проблемы экологического образования и воспитания в России” (22 сентября 1998г.); решения ряда конференций по экологическому образованию.

Все эти факторы стимулировали дискуссию о дальнейших путях развития отечественного экологического образования. В 1990-е гг. активизировалось российское общественное экологическое движение. В 1993 г. была сделана попытка объединить и поддержать отдельные разрозненные группы энтузиастов в рамках программы “Семена демократии". Программа была нацелена на развитие и укрепление общественного экологического движения в странах СНГ. Она строилась на принципах открытости, прозрачности и доступности для всех заинтересованных в ней организаций. Гранты распределялись на конкурсной основе по решению экспертного совета, состоявшего из авторитетных специалистов в области экологического образования и лидеров экологического движения. К конкурсу допускался любой проект, который мог принести пользу охране окружающей среды и заканчивался конкретным результатом. Проекты, получившие финансирование, распределялись следующим категориям: a) работа с особо охраняемыми территориями, охрана природы в городе; б) защита прав граждан на жизнь в здоровой окружающей среде; в) экологическое образование. По окончании действия программы был создан компьютерный банк данных о работе общественных экологических организаций в России.

3.2 Комплексный характер экологического образования

3.2.1 Экологическое воспитание в семье как основа формирования экологической культуры

Российская семья представляет собой микросрез социума. Поэтому все тенденции, обусловленные глубокими процессами перспективного преобразования экономики и управления, происходящие на современном этапе жизни общества, в полной мере распространяются и на российскую семью. Под влиянием глубоких процессов демократизации и гуманизации в России формируется экологическая культура каждого члена социума, которая происходит параллельно социализации личности в процессе поэтапного социального становления. Именно в семье начинается первое формирование экологического сознания, которое формирует модели экологического поведения в дальнейшем на разных периодах развития человека.

Экологическое поведение детей определяется одним из наиболее мощных факторов развития сознания как потребность познания, любознательность. Познание через действие - основная форма экологического поведения детей, которое позволяет им классифицировать окружающий мир, разделять его объекты и процессы. Бережное, природоохранительное отношение к природе может быть привнесено только социальной средой. В этом и должна состоять главная задача экологического воспитания в семье. Экологическое воспитание детей на первых 
этапах предусматривает необходимые экологические знания о животных и растениях, разнообразие окружающего мира. Должны быть освещены вопросы взаимосвязи животных и растений - они могут существовать только тогда, когда они целы и взаимодействуют. В этот период проводится работа по определению сходства и различий между живыми организмами (животные, растения, человек). Однако не следует упускать из внимания вопрос о человеке как части природы, о его прямой зависимости от природы, свойственной всем живым организмам. Желательно, чтобы в процессе общения с ребенком прослеживалась тема органичной связи сезонных проявлений природы с временами года, цикличности природных явлений и процессов, существующей взаимосвязи в природе. Можно увязать эти явления с фенологическим, астрономическим, народным и социальнобытовым календарями. Для более глубокого и заинтересованного изучения природы необходимо использовать наблюдения, моделирование, опыты, труд, игры, рисование, лепку, конструирование с природными материалами и другие виды деятельности. При этом у ребенка несомненно будет раскрываться и развиваться индивидуальный творческий потенциал. Можно порекомендовать проводить упражнения с детьми старшего дошкольного возраста в распознавании 4-6 видов комнатных растений по форме, окраске листьев, цветов, стеблей; знания их названий. Различать их по окраске листьев - светолюбивые и теневыносливые растения; по толщине стеблей и листьев - влаголюбивые и засухоустойчивые растения. Приучать к уходу за растениями, учитывая их потребности в свете и влаге, в зависимости от периода развития; выявлять и пересаживать комнатные растения, требующие смены почвы. Дети приучаются к труду по их выращиванию, приобретают трудовые навыки по уходу за растениями. Работа по выращиванию растений должна наглядно показать детям, что, изменяя условия их жизни, человек может управлять развитием растений. Это будет способствовать воспитанию у детей зачатков материалистического мировоззрения и приобщения растущей личности к культуре. Таким образом, модель экологической культуры каждого человека будет закладываться, в первую очередь, в семье, а затем в период дошкольного воспитания, развиваться в подростковом возрасте, и формироваться в зрелые годы, и лишь у пожилых людей можно будет считать ее полностью сложившейся (не исключая влияния образовательной и информационной сред).

Проблема сохранения здоровья актуальна не только для взрослого населения, но и для подрастающего поколения. Повсеместно отмечается снижение активности школьников, замедление их психофизического развития, возникновение асоциальных отклонений в поведении. Общеизвестно, что из детского сада в школу приходит 90\% здоровых детей, а по окончании еe цифра достигает лишь $10 \%$. Следовательно, за время пребывания в школе, в ходе обучения ученик не только повышает уровень своих знаний, но и теряет здоровье. Поэтому задача приобщения детей к решению проблемы сохранения и укрепления своего здоровья вошла в разряд первоочередных. Именно в семье одной из приоритетных задач должна быть провозглашена задача гигиенического воспитания ребенка, формирования у него здорового образа жизни, обеспечивающего сохранение физического, психического и нравственного здоровья.

Таким образом, основная цель семейного экологического воспитания заключается в том, чтобы сформировать у ребенка нравственные, познавательные, эстетические основы рационального отношения к окружающему миру, прежде всего в области природопользования, развить новое экологическое мышление, способное прогнозировать последствия действий человека по отношению к окружающей среде.

3.2.2 Дошкольное воспитание в контексте экологической культуры России

Анализ литературных материалов позволил сделать вывод о том, что современное российское экологическое образование в дошкольной педагогике формируется на основе нескольких составляющих и значительно отличается от подобного в других странах.

1). Традиционные для российской педагогики подходы. Такой подход базируются на ознакомлении детей с природой, тесном контакте детей с окружающим миром, наблюдениях, походах. С одной стороны, это развивает в ребенке нравственные начала, способность видеть, чувствовать и понимать красоту природы, с другой - развитие познавательного интереса, рассмотрение природы как универсального объекта для обучения ребенка. Так, В.А. Сухомлинский обращал внимание на использование природы для умственного и нравственно-эстетического развития [13, с.45]. К.Д. Ушинский рекомендовал расширять познание природы ребенком и общение с нею [15, с.40]. Это направление создает хорошую базу для перехода к экологическому образованию детей и тесно с ним связано. Однако механический перенос содержания и методики работы с детьми по ознакомлению с природой на экологическое образование не подменяет его. Кроме того, 
природоохранный аспект ознакомления с природой в течение продолжительного времени (50-80 гг. XX века) отражал характерные для того времени взгляды на всемогущество человека как хозяина, покорителя природы, что не соответствует современной экоцентрической парадигме.

2). Народные традиции. Народные сказки, праздники, приметы, игры разных народов отражают определенный уровень восприятия природы людьми, их отношение к ней, особенности использования природных ресурсов. В творчестве народа прослеживаются этнические особенности взаимоотношений человека с природой. Интерес детей младшего возраста к играм, сказкам, загадкам делает особо перспективным использование элементов различных культур в целях экологического образования.

3). Зарубежные технологии. В настоящее время зарубежные технологии слабо представлены в массовой практике экологического образования дошкольников. Одна из причин - различие в подходах к содержанию и организации дошкольного образования в России и зарубежных странах. В европейских странах и США нет так называемых парциальных программ для детских садов. Наиболее известны в нашей стране разработки специалистов США, в которых большое внимание уделяется чувствам ребенка, способности наблюдать в природе, умению оценить ее разнообразие, разбудить чувство удивления и восхищения. В литературных источниках есть также информация об экологическом образовании в детских садах Германии. В большинстве случаев зарубежные материалы представляются в виде описания конкретных технологий (игр, исследований и т.п.) без теоретического обоснования и рассчитаны на детей старшего дошкольного и младшего школьного возраста. Многие зарубежные рекомендации не соответствуют российским традициям, и из использование возможно лишь после адаптации к условиям российского дошкольного образования.

4). Отечественное экологическое образование в дошкольных учреждениях. Анализ опыта работы дошкольных учреждений выявил, что отсутствие достаточного количества методической литературы вынуждало воспитателей дошкольных учреждений применять элементы содержания школьных учебников (в первую очередь для начальной школы) и соответствующую методику обучения в детских садах. При этом информация недостаточно адаптировалась, слабое понимание самим воспитателем экологических проблем приводило к тому, что он строго следовал предлагаемым в литературе рекомендациям и, зачастую недоступной и ненужной для дошкольников. Такой подход ведет к потере интереса детей к познанию окружающего мира и перегрузке излишней их информацией. Содержание и методы школьного экологического образования не должны механически переноситься в дошкольные учреждения, хотя и учитываются при рассмотрении вопроса преемственности «дошкольная ступень начальная школа».

На основе анализа особенностей формирования в регионах страны системы непрерывного экологического образования, и ее первой - дошкольной - ступени выделены различные варианты становления экологического образования дошкольников. Первый из них определен как стихийный, второй - как системный. В стихийном варианте коллектив дошкольного учреждения самостоятельно использует известные программы или создает собственные в рамках своего понимания. Во другом случае, сначала разрабатывается общая региональная концепция непрерывного образования, а уже в ней отводится конкретное место отводится дошкольному звену.

В методике дошкольного экологического воспитания рекомендуется создание уголка живой природы. Впервые они были введены в младших классах гимназии и реальных училищах известным русским педагогом и методистом А.Я. Гердом. Он считал, что основной задачей первоначального обучения должно быть развитие ума ребенка. С этой целью процесс обучения должен обязательно включать наблюдения, знакомящие детей с жизнью природы в ее непосредственных и естественных проявлениях. А.Я. Герд стремился обеспечить «живое соприкосновение» ребенка с природой, участие в ее жизни. Этой цели и служили уголки живой природы. Предложение об организации своеобразных уголков природы для детей дошкольного возраста было выдвинуто Е.Н. Водовозовой, известной в истории русской дошкольной педагогики своими прогрессивными взглядами [2, с.72]. Ее заинтересовали идеи А. Герда о необходимости тесной связи обучения с жизнью, об использовании активных методов. Она рекомендовала использовать для детей «естественные кабинетики», в которых помещались аквариум, птицы в клетке, садки с насекомыми. Дети бы в них выращивали «растения в горшках», наблюдали и экспериментировали.

В настоящее время всё большее количество дошкольных учреждений в нашей стране включается в решение проблем экологического 
образования. Как утверждает С.Н. Николаева, основой экологического образования является формирование экологического мировоззрения у педагогов и детей [9, с.67].

Экологическое мировоззрение - это продукт образования; его становление происходит постепенно в течение многих лет жизни и учения человека. Начинается этот процесс с возраста, когда закладываются первые основы миропонимания и практического взаимодействия с предметно-природной средой. В дошкольном учреждении ребенок находится в течение длительного периода. Здесь нет жесткой регламентации его деятельности, традиционно большое внимание уделяется развивающей предметной среде, создаются оптимальные условия для формирования у детей основ экологического мировосприятия. Важно и уместно упомянуть об использовании родительского фактора: именно родители заинтересованы в активном воздействии с педагогами.

Историко-педагогический анализ становления дошкольного экологического образования позволяет сделать следующие выводы:

1). Дошкольное экологическое воспитание это новая социальная категория, которая непосредственно связана с экологией, с различными ее ответвлениями. В основе ее лежат концептуальные основы экологии: организм и среда, сообщество организмов и среды, человек и среда.

2). Дошкольное экологическое образование это целенаправленный педагогический процесс, обладающий высоким развивающим потенциалом, который позволяет развивать в человеке его психические процессы (внимание, память, мышление, воображение и т.д.) и способности (интеллектуальные, творческие, музыкальные, лингвистические и т.д.).

3.2.4 Школа как механизм социальной мобильности в формировании экологической культурье

Попробуем ответить на такие вопросы: может ли образование бросить вызов разрушительным тенденциям, обеспечить прогресс цивилизации? Каковы приоритеты и ценности экологического образования в школах, соответствуют ли они запросам общества, человека? Какова мера ответственности образования за решение глобальных проблем?

Слабое звено российских реформ системы образования - отсутствие четких представлений о том, какой цели мы придерживаемся и к чему должны прийти в ходе ее реализации. Если система образования призвана целенаправленно обеспечивать воспроизводство существующих социальных классов и групп, то на какие классы и группы ориентировано сегодня российское образование? В этих условиях реформа системы образования в целом, и экологическое образование в частности, должна быть сориентирована на человека, а общие, довольнотаки обтекаемые штампы - модернизация, фундаментализация, гуманизация, индивидуализация - уступить место деятельности, отвечающей социальным ожиданиям. Решение этой задачи предполагает не только внедрение новых учебных технологий, которые способны преодолеть анемичность в рамках той или иной профессии, но и формирование у будущих специалистов способности к осознанному участию в социальных процессах. Несмотря на актуальность и необходимость воспитания экологически грамотных граждан, активно участвующих в деле охраны окружающей среды своего региона, экологизация системы школьного образования проходит медленно. Как считают Д.Н. Кавтарадзе, А.А. Брудный [5, с.26], реализация целей и принципов экологического образования затруднена, если мотивацией для приобретения экологических знаний для ученика является получение положительной оценки, а не понимание необходимости воплощения экологических знаний в повседневной жизни.

Как уже было сказано, большие возможности для экологического образования и воспитания заложены в естественнонаучных предметах. Решение проблем экологического воспитания учащихся среднего школьного возраста в процессе изучения естественнонаучных дисциплин выдвигает ряд вопросов, ответ на которые требует определения того, какими экологическими знаниями, умениями и навыками следует вооружить учащихся средних школ, какие черты характера и свойства личности необходимо развивать.

Перед средней школой стоит задача формирования экологической культуры учащихся. Это предполагает выработку системы экологических знаний, умений и навыков учащихся. Формирование экологической культуры необходимо проводить по следующим направлениям:

a) формирование системы знаний о среде обитания человека, ее качествах, факторах формирования, закономерностях развития;

б) формирование умения оценивать влияние различных факторов на среду и ее качества с помощью доступных методик, осуществлять прогноз;

в) воспитание экологического стиля мышления;

г) воспитание эстетического взгляда на 
окружающую среду, бережное, ответственное отношение к природе;

д) воспитание экологически оправданного поведения

Чтобы решить данные задачи, целесообразно провести комплекс мероприятий: в соответствии с содержанием экологического образования обновить учебники и программы по предметам естественнонаучного цикла, включить в них современный материал по экологическим проблемам; создать методические материалы по различным аспектам экологии регионов [17, с.255]; сформировать систему непрерывного образования и воспитания учащихся на межпредметной основе.

3.3 Система экологического образования в российских вузах

Смена государственно-политического строя в России в начале 1990-х гг. дала жизнь многим реформам, целесообразность некоторых из них оспаривается специалистами до сих пор. Своеобразие понимания рынка, желание перевести экономику страны, ее основные социальные институты на рельсы коммерциализации отразилось и на моделях реформирования высшей школы, спровоцировав обострение борьбы между представителями различных направлений. Предстояло выбирать между:

1) деидеологизацией и деполитизацией содержания социально-гуманитарного знания и новыми идейными и культурными ценностями;

2) демократизацией жизни вуза и стабилизацией учебных дисциплин;

3) массовостью и элитарностью образования;

4) многообразием форм и методов обучения и сохранением единства требований к качеству получаемого обучения;

5) автономностью вуза (условие сохранение его академического статуса) и углубляющейся его зависимостью от источников финансирования;

6) множественностью взглядов, концепций, культурных ценностей и стремлением к единству и определенности, доминирующей концепции (условие преодоления социальной разобщенности);

7) углубляющейся специализацией и потребностью в системном, интегрированном образовании.

Тем не менее, возникшее вначале 1990-х гг. снижение абсолютной численности студентов некоторые эксперты связали с падением престижа высшего образования. В действительности же абсолютное уменьшение контингента как из числа поступающих, так и обучающихся следует рассматривать как своеобразную реакцию на тот «хаос неопределенности», который ученые окрестили социокультурным кризисом. Именно период блуждания и хаоса (1989-1995 гг.) поставил каждого россиянина, и молодежь прежде всего, перед проблемой выбора вариантов действий, повседневного поведения. И молодое поколение россиян сделало свой выбор. Применительно к экологическому образованию это означало, что должна быть создана модель образовательной системы, которая смогла бы найти выход из кризисного состояния, адаптировав экологическое образование в частности к новой модели экологической культуры. Образование с этой точки зрения должно представлять собой управляемую опережающую систему, которая предвидела бы и удовлетворяла потребности не прошлого, как это имеет место сейчас, а формируемого общества. Разумеется, в модели опережающего образования найдется место и для прошлого и настоящего, поскольку образование должно носить всеобщий и непрерывный характер. Понятие опережающего образования не употребляется в педагогической науке, и лишь иногда говорят об элементах опережения в отстающем от жизни и науки в целом образовании. В последнее время появилось понятие "развивающее образование" и понятно, что "опережающее образование" должно включать в себя основные принципы развивающегося образования. Более того, сама система опережающего образования должна быть саморазвивающейся системой и одним из основных механизмов формирования ноосферной цивилизации на пути устойчивого развития Кроме того, в настоящее время завершился этап формирования научно обоснованных предпосылок и положений, связанных с осознанием места и роли экологического информирования и образования в системе мер по обеспечению национальной безопасности России. На уровне принятия законодательных и управленческих решений возникло понимание необходимости увязки вопросов обеспечения экологической безопасности с повышением уровня общественного экологического сознания. Развитие экологической информатизации и наращивание возможностей компьютерного моделирования глобальных природных и социально-экономических процессов, переход на безбумажные способы накопления и передачи информации и создание глобальных коммуникаций, создание единого информационного пространства и планетарного экологического мониторинга и управления социоэкоразвитием. Речь, в конечном счете, идет о формировании постиндустриальной информационной цивилизации как первой 
ступени становления ноосферы на пути реализации модели устойчивого развития.

\section{Обсуждение}

Экологическое образование имеет глобальное, общечеловеческое значение. Видимо поэтому его проблемы привлекают значительное внимание как на региональном, так и на международном уровнях, о чем свидетельствуют многочисленные форумы и конференции. Экологическое образование призвано стать инструментом преобразования общественного и индивидуального экологического сознания. Основы экологического воспитания были изложены в программе “Экологическая безопасность России" (в 1993-1995 гг.). В ней были даны рекомендации по разработке пакета программ и методические указания по содержанию, формам и методам экологического образования и воспитания - от дошкольного до высшего. Вместе с тем следует признать, что постановка экологического образования в учебных заведениях оставляет желать лучшего: затягивается введение специального курса по охране окружающей среды и рациональному использованию природных ресурсов, который должен стать составной частью процесса образования во всех средних и высших учебных заведениях. Далеко не везде идет переработка различных предметов и курсов в плане их сопряжения с вопросами экологии: материал излагается часто без акцентирования внимания на печальном состоянии земель, вод, лесов и т.д. В дошкольном экологическом образовании еще много нерешенных проблем. В учебном процессе не стимулируется эколого-познавательная активность обучаемых, стремление проникнуть в глубинные тайны природы, элементарные умения и навыки научного поиска. Особенную актуальность приобретает проблема подготовки эколого-педагогических кадров, в частности, методистов, воспитателей для дошкольных учреждений. Но несмотря на объективные трудности в процессе формирования непрерывности экообразования, как показывает практика в последние 20 лет была осуществлена масштабная экологизация общества, что выразилось в свою очередь на экологизации школьных дисциплин, в первую очередь предметов естественнонаучного цикла: биологии, географии, химии. В настоящее время в образовательных учреждениях практикуются следующие модели экообразования: однопредметная, многопредметная и смешанная модель. Однопредметная модель сводится к наличию в программе одного предмета, например, экологии. Многопредметная модель заключается в том, чтобы каждый учебный предмет содержал экологические аспекты.
Наиболее востребованной является смешанная модель. Она заключается в укреплении экологического содержания всех предметов на межпредметной основе, внеурочной и внешкольной деятельности и введение одного специального предмета в программу.

В учебниках по этим дисциплинам введены новые или расширены уже имеющиеся главы и параграфы экологической направленности. Например, к учебникам по физике для 7 и 8 классов А.П. Рыженковым написаны приложения: “Физика. Человек. Окружающая среда" [12, с.3]. Вопросы экологии были включены в программы по природоведению для начальной школы. А.Н. Захлебным разработана концепция и создана программа преподавания интегрированного предмета "Естествознание" в основной школе, которое согласно его концепции следует рассматривать как предмет экологического содержания [4, с.15]. Поэтому наряду с экологизацией школьных предметов в 1990-е годы разрабатывались отдельные новые курсы по экологии, были написаны программы и учебники, раскрывающие экологию с разных позиций. Учебники Б.М. Миркина и Л.Г. Наумовой акцентируют внимание на вопросах природоохранного характера. В них подробно рассматриваются естественные и искусственные (городские, промышленные, сельскохозяйственные) экосистемы России, а также возможные источники их загрязнения. По мнению Ю.П. Трусова, в качестве исходного должно выделяться понятие экологического взаимодействия, согласно другим авторам понятие экосистемы и т. д. [14, с. 4]. Одна из такого рода попыток связана с предложением исходить из понятия экоразвития как интегрального развития экосистемы, на основе которого были даже построены матрицы экоразвития. Однако нужно отметить, что логика научного развертывания общей экологии далеко не всегда прямолинейно может быть использована в педагогическом процессе, поскольку на образование влияют многие иные обстоятельства. Например, в схеме логического развертывания экологического образования, автором которого является Н.М. Мамедов, предполагается, что предметное поле экологии начинается с понятия экосистемы как экологической единицы окружающей среды [7, c.54]. Затем последовательно вводятся понятия экологического взаимодействия, экологического развития, экологической проблемы и, наконец, понятия устойчивого развития экосистем. Вполне понятно, что подобная (онтологическая) схема развертывания логики вполне приемлема и она, так или иначе, может быть не столь строго, но реализоваться в ряде учебных пособий по 
экологии, в частности, для средней школы. Учитывая диверсификацию экологического образования по направлениям научных знаний можно высказать мнение, что упомянутые выше логические схемы более применимы для естественнонаучного направления образования. Вообще в зависимости от учебного заведения специальности могут выбирать иные логические схемы развертывания экологического знания в образовательном процессе. Что касается социально-экологического направления экологического образования, то может быть предложена еще одна - новейшая логическая схема, которая в том или ином виде может быть модернизирована во всех видах и уровнях экологического образования. В основу этой схемы положена идея опережающего образования - от нормативного (желаемого) прогноза развития системы «общество природа» к действиям по его реализации для решения экологической проблемы.

\section{Заключение}

C позиции социальной экологии экологическое образование является важным фактором сохранения и развития общечеловеческого наследия. При таком подходе современная цивилизация выступает как интегральное целое, которое можно разбивать на свои материальные и духовные части. Социальная экология вносит вклад в развитие равновесия между гуманитарной составляющей и технической, с целью сохранения и развития общечеловеческого наследия. Многообразие экологических проблем создает определенные трудности в подборе для преподавания и изучения студентами наиболее актуальных материалов, но в целом тематика курсов четко очерчена, чего не скажешь о самом понятии “экология”. В повседневном обиходе это слово приобрело избыточно обширный, буквально безразмерный смысл, причем особенно часто его употребляют в качестве синонима “охраны окружающей среды”. В англоязычной литературе четко различают понятие “есology” как наука и "environmental welfare" как особый род деятельности людей, направленный на снижение ущерба, наносимого человеком природе и самому себе. В русском же языке произошло смещение этих понятий, часто ставится знак равенства между экологией и технологией. Это, на наш взгляд, недопустимо, поскольку такой подход автоматически возлагает ответственность за загрязнение окружающей среды вследствие несовершенных технологий на экологов, а не на те отрасли хозяйства и тех специалистов, которые их разрабатывают и используют.

Обучение должно быть связано с формированием знаний о системной организации природы, развитием системы интеллектуальных и практических умений молодого поколения по изучению, оценке и улучшению состояния окружающей среды своей местности и здоровья людей [16, с.169]. Таким образом, методологическим основанием экообразования является современная научная картина мира, в которой центральное место занимает проблемноориентированная экология. На это положение следует опираться при планировании и осуществлении не только экологического образования, но и любого другого на всех уровнях. Коэволюционный подход к экологическому образованию основан на признании идеи построения общества устойчивого развития в качестве основной цели, стоящей перед человечеством. Осознать все эти моменты весьма важно в контексте экологизации общества, размышление над ними влечет некоторые промежуточные выводы и рекомендации, а именно для решения комплекса проблем экологического образования целесообразно рекомендовать: создание единой национальной системы всеобщего экообразования и воспитания на федеральном, отраслевом и региональном уровнях; совершенствование законодательной базы; выработку научнообоснованной государственной стратегии в данном вопросе; совершенствование процессов взаимодействия всех звеньев системы непрерывного экообразования; создание информационного обеспечения этой системы; разработку научнометодического обеспечения; совершенствование кадровой политики; активное привлечение средств массовой информации к реализации образовательных экологических программ; увеличение издания экологической литературы; усиление государственной и общественной поддержки экологического образования и распространения экологической информации; развитие международного сотрудничества в области экологического просвещения и образования.

\section{References:}

1. Vladimirskiy-Budanov M (1974) Gosudarstvo i narodnoe obrazovanie v Rossii s XVIII-go veka
/ M.F. Vladimirskiy-Budanov. Ch. 1. Yaroslavl': Tip. G.V. Fal'k, 1874. - pp.325. 
2. Vodovozova E (2010) Tsarstvo svobodnogo rebenka. Moscow: Karapuz, 2010. pp.288.

3. Zavalova N, Lomov B, Ponomarenko V (1986) Obraz v sisteme psikhicheskoy regulyatsii deyatel'nosti. Moscow: Nauka, 1986. pp.173.

4. Zakhlebnyy A, Suravegina I (1984) Ekologicheskoe obrazovanie shkol'nikov vo vneklassnoy rabote. - Moscow: Prosveshchenie, 1984. pp.29.

5. Kavtaradze DN, Brudnyy AA (1993) Osnovy ekologicheskogo mirovozzreniya kak zadacha obrazovaniya dlya ustoychivogo razvitiya. // Vestnik obrazovaniya, № 3, pp.2-40.

6. Komenskiy Y (2009) Uchitel' uchiteley: Izbrannoe. Moscow: Karapuz, 2009. pp.288.

7. Mamedov N (1996) Ekologicheskoe obrazovanie: kontseptsii i metodicheskie podkhody. /Otv. Red. Mamedov N.M. Moscow: Agentstvo «Tekhnotron», 1996. pp. 136.

8. Marks K (1987) Kapital. Tom 1.: Available: http://www.litres.ru/karl-marks/kapital-tompervyy (Accessed: 14.03.2015).

9. Nikolaeva S (2002) Vospitanie ekologicheskoy kul'tury v doshkol'nom detstve: Metodika raboty s det'mi podgotovitel'noy gruppy detskogo sada: Posobie dlya vospitatelya doshkol'nogo obrazovatel'nogo uchrezhdeniya. - Moscow: Prosveshchenie, 2002. pp.144.

10. Piskunov A (2001) Istoriya pedagogiki i obrazovaniya: Ot zarozhdeniya vospitaniya $\mathrm{v}$ pervobytnom obshchestve do kontsa XX v.:
Uchebnoe posobie dlya pedagogicheskikh uchebnykh zavedeniy / Pod redaktsiey A. I. Piskunova. - Moscow, 2001. pp.512.

11. Romanov B (2011) Vestnik, ili zhizn' Daniila Andreeva. - Moscow: Feoriya, 2011. - 640 p.

12. Ryzhenkov A (1996) Fizika. Chelovek. Okruzhayushchaya sreda. Moscow: Prosveshchenie, 1996. pp. 164.

13. Sukhomlinskiy V (1970) Shkola i priroda. // Sovetskaya pedagogika. 1970. - № 5. - pp. 45.

14. Trusov YP (1983) O predmete i osnovnykh ideyakh ekologii. Moscow, 1983.

15. Ushinskiy K (1948) Izbrannye pedagogicheskie sochineniya. Tom 2. Moscow: 1948. - pp.648.

16. Khetagurova V, Bryukhanova G, Vaulin N (2014) Osobennosti ekologicheskogo obrazovaniya $\mathrm{v}$ sel'skoy shkole (na primere Podmoskov'ya): // V sbornike: Fundamental'nye i prikladnye issledovaniya: problemy i rezul'taty. Trudy mezhdunarodnoy nauchno-prakticheskoy konferentsii. Moscow, 2014. pp. 169-174.

17. Khetagurova VS, Bryukhanova GA, Vaulin NY (2014) Ekologo-istoricheskaya sistema ekologicheskogo obucheniya i vospitaniya na territorii Podmoskov'ya. // V sbornike: Dostizheniya vuzovskoy nauki. Trudy mezhdunarodnoy nauchno-prakticheskoy konferentsii. Moscow, 2014. pp. 255-260. 